\title{
Articles
}

\section{The Teacher's Role in the Reflection of Social Disadvantage ${ }^{1}$}

\section{Vladimíra Kocourková, Anna Šafránková}

\begin{abstract}
The paper attempts to explain the definition of socially disadvantaged pupils and the role of teacher in the Czech educational environment, because the characterization of this specific group of pupils is one of the important preconditions for setting adequate support and compensation precautions. The teacher is one of the important participants of inclusive educational environment and in a crucial position in terms of education of socially disadvantaged pupils is. The authors analyze the partial results of a research survey that was carried out in the Pardubice Region and in the MoravianSilesian Region on the educational levels ISCED 1 and ISCED 2 and that aimed to identify partial characteristics of individual teachers' attitudes to socially disadvantaged pupils. The study presents the partial results obtained using semantic differential. The premise was that between observed groups of teachers were significant differences in the perception of the stated conceptual indicators.
\end{abstract}

Key words: social disadvantage, semantic differential, attitudes, teacher, identification of social disadvantage.

The contribution was written in the grant project IGA PdF_2012_043 titled Analysis of Educational Aspects of Socially Disadvantaged Pupils. 


\section{Introduction}

The profession of a teacher can be perceived in a close relation to educational potential of society and its development; a teacher is a bearer and mediator of education and plays a key role in the area of functioning of educational systems. Equally important is the teacher's reflection and, in some respects, anticipation of the society dynamics (Vašutová In Maňák, Jůva, 1998, p. 172).

Kellaghan (In Rabušicová, 2004, p. 22) states that despite the fact that family and school differ from the viewpoint of priorities, requirements, expectations, in organization of time and space, in their relationship to children and many other aspects, these two institutions share a common objective - to ensure an optimum development of a child. It is possible to talk about the complementary role of family and school in this context. The family variables can be thus perceived as significant determinants which can influence pupils' education (Starý, Dvořák, Greger, Duschinská, 2012). The first dialogue between a pupil and the educational system is usually realized in the school environment where the main role in education and optimization of the educational process is played by the teacher.

Thus it is logical that the tendency of accentuation of discussions in the field of teachers' professional development is increasing in both the conceptual and research areas at the present; this can be characterized as a "set of activities leading to the perfection of the execution of the profession of a teacher and the improvement of pupils' learning outcomes". (Starý, Dvořák, Greger, Duschinská, 2012, p. 12).

As stated above, despite the fact that the area of teachers' professional development can be examined from many perspectives ${ }^{2}$, the contribution focuses on the characterization of the significance of a teacher, the definition of the group of socially disadvantaged pupils in the context of the Czech educational environment and the presentation of outcomes of a research survey focused on the identification of its partial components of attitudes in relation to socially disadvantaged pupils because we think in correspondence with J. Pelikán and Z. Helus (1984) that pupils' education can be perceived, beside others, through the prism of their teachers; it is exactly the teachers' attitudes to pupils that indirectly influence the overall atmosphere in the class, and also influences particular pupils as well as the teachers' interaction with the particular class in return. In this sense it is also possible to consider the transmission of teachers' opinions towards children in correspondence with social-cultural transmission in the process of socialization - in some cases on the unconscious functional level.

2 This fact is evident also on the basis of a systematic analysis of the hitherto foreign sources related to the profession of a teacher in the book Profesní rozvoj učitelů, podpora učitelů pro zlepšení výsledkủ žáků (Starý, Dvořák, Greger, Duschinská, 2012) 


\section{Theoretical framework of the research survey - socially disadvantaged pupil}

The mechanism of disadvantage on the basis of a child's social environment can be undoubtedly perceived from many perspectives. Social disadvantage can be related to a different cultural, value orientation and the mother tongue different from the school language. No less important factor related to social disadvantage is socioeconomic status (SES) of the child's family. On the basis of an OECD research (2012) it was found out that pupils from an disadvantaged socioeconomic environment are twice more likely to be less successful in education. A family's socioeconomic status positively correlates with the parents' investments in their children's future (Conger, Dogan, 2007). In this context it is possible to think of the assumption that families of higher socioeconomic status invest more time, finances, energy in their children's development and can place greater demands for academic success of their children. (Conger, Donnellan, 2007). Similarly, Kellaghan (1997) says that SES influences not only pupils'school outcomes but also the level on which children finish their education. The correlation of pupils'school success and their families' socioeconomic status is also dealt with by a PISA international research. The outcomes of this international research confirmed the correlation of pupils'school outcomes in reading literacy and socioeconomic statuses of children's families in the Czech Republic in 2009. (Palečková, Tomášek, Basl, 2010) The influence of the social and family environment on pupils' school outcomes was the object of examination in one of the best known studies by the sociologist Colman (1966). Beside others, this study proved that students from minorities or a financially poor family background or a segregated environment are influenced by their family background to such an extent that they reach poorer school outcomes more frequently than their classmates. What is important for a child beside the family's social capital according to Coleman (1988) is social capital of the community where the school is situated.

The definition of social disadvantage was elaborated in a more complex way by Havighurst (1961) as one of the first authors; he specifies socially disadvantaged pupils on the basis of three aspects: the characteristics of the child's family, the child's personality features and the family's social environment. J. Cleg and J. Ginsborg (2006) add that the definition of social disadvantage is not easy, and thus the characterization of this phenomenon by means of the family's socioeconomic status is frequently encountered.

Social disadvantage can be understood as a state formed by a combination of factors influencing a child's education. The form and scope of disadvantage can come in various shapes.

The group of socially disadvantaged pupils are included in the group of pupils of special educational needs from the viewpoint of the Education Act in the Czech Republic. According to this act socially disadvantaged pupils are: 
- individuals coming from a family background of a low social cultural position;

- at risk of social pathological phenomena;

- individuals who have been ordered institutional care or adjudicated protection in a young offender institution;

- asylum seekers and participants in asylum procedure in the territory of the Czech Republic (s. 16 (4) Act no. 561/2004 Coll.).

The Framework Educational Programme for Elementary Education defines this group of pupils as individuals coming from a family background of a low social cultural and economic position for whom the integration into the educational mainstream can present difficulties due to language differences or due to their and their families' cultural patterns showing in behaviour, conduct, different value hierarchies, life styles, concepts of upbringing of children and relationships to education (Jeřábek et al., 2005).

It is evident that the issue of social disadvantage is very wide. One of the indicators of social disadvantage is the family's poverty that can be a consequence of many factors such as family break-up, failure of educational system, economic dependency, addictions or indebtedness (The Centre for Social Justice, 2006).

One of the factors necessary for adequate education of socially disadvantaged pupils is their individual support provided by their families which is not a matter of course as it is in the case of pupils without social disadvantage. Families which are not socially disadvantaged frequently invest a lot of money and time in their children's education beyond the scope of compulsory education in order to provide their children with quality education. (The Centre For Social Justice, 2007). It can be said in general that a family that is comfortably well-off is able to provide their child with stimulating toys, broaden the child's knowledge and skills by means of travelling and cultural and educational activities, do diverse sports with the child and, last but not least, provide the child with quality food, and thus form a basis for healthy eating habits. (Možný, 2002).

It is evident from the above brief characteristic of socially disadvantaged pupils that their exact definition is not easy (Němec, Vojtová, 2009). Education of these pupils can present a difficult task not only for particular educational policies dealing with this issue also from the perspective of the so-called inclusive education but also for teachers who are in everyday interaction with these pupils.

\section{Role of a teacher in relation to socially disadvantaged pupils}

The presence of socially disadvantaged pupils in the educational process places specific demands on teachers, including awareness, preparation for the multicultural environment in the class, social and communication competences related also interaction with 
families of these pupils (obtaining relevant information of the pupil's situation not only within the school life but also after-school life adequately) and others. Wehlage (In O'Sullivan, Gilligan, 1997) believes that there are four values forming a teachers' positive character and providing them with support for successful integration of socially disadvantaged pupils into the educational process. These are:

- acceptance of responsibility for pupils' achievements;

- teachers' belief in their practice and role;

- acceptance of the need of being persistent in relationship to these pupils who are frequently not ideal;

- manifestation of certain optimism and thus building on pupils' strengths and positive aspects.

A teacher provides specific care, motivating and activating teaching methods and forms of education developing individual conditions of pupils and strengthening positive perception of a heterogeneous team (Ministerstvo školství, mládeže tělovýchovy, 2009).

The issue of teachers' characteristics and their influence on education and performance in education can be found in a number of researches. One of the best known above mentioned researches, focusing on the area of equal opportunities in education, was conducted under the leadership of the American sociologist A. Coleman (the research report is frequently referred to as the Coleman report and is titled Equality of Educational Opportunity) in the 1960s in the USA. Beside others, this research focused on teachers' characteristics, attitudes and their influence on education of socially disadvantaged pupils. (Sheerens 2004, p. 3)

The issue of attitudes and their influence in general has been dealt with by many researchers; nevertheless highly specific researches in teachers' attitudes to their pupils are less represented (e.g. Potměšil, 2010), researchers in teachers' attitudes to pupils with social disadvantage are rather unique in the Czech environment. It is possible to assume on the basis of some conducted research surveys (e.g. Helus, Pelikán, 1984) that a teacher's attitude can influence a pupil's educational activities.

The contribution focuses namely on capturing differences in perception of connotative meanings of terms on the basis of an opinion that the role of a teacher in education of socially disadvantaged pupils is a complex issue of a multidimensional character because it is conditioned by many influences forming a complex. In this context it is rooted in the research in attitudes in the educational process by J. Pelikán and Z. Helus (1984) who found out that teachers' preference attitudes towards pupils influence indirectly the overall atmosphere in the class too, and influences back individual pupils as well teachers' interaction with the particular class. A particular pupil and his or her conduct and behaviour is always confronted with the idea of an ideal pupil the teacher has subjectively created in the teacher's consciousness (or subconsciousness) as well as other classmates. We believe that similarly to the above mentioned research 
by J. Pelikán and Z. Helus (1984) (where pupils of a higher index of adaptability, pupils of a quieter, more silent nature, standing out due to their activity and temperament got better evaluations) pupils who stand out from the "average" in a way will be undervalued. Such pupils may include also socially disadvantaged pupils (Kocourková, Šafránková, 2011).

\section{Selected conceptual indicators from the perspective of semantic differential}

\subsection{Purpose of the research survey}

A part of the research survey was focused on finding the difference in individual perception of conceptual indicators related to the area of education of socially disadvantaged pupils. A difference between the final semantic space of teachers in the Pardubice and Moravian-Silesian region was also observed. One of the indicators of social disadvantage can be unemployment of parents and poverty arising from it. The selection of the research sample was intentional because the Moravian-Silesian Region is understood as one of the regions of the highest unemployment rate according to the data of the Czech Statistical Office, and thus it is possible to assume an increased number of socially disadvantaged pupils at schools. On the contrary, the Pardubice Region is a region of the sixth lowest unemployment rate in the Czech Republic in comparison with other regions. (Český statistický úřad, 2011) We assume that social characteristics of the regions also influence the perception of particular conceptual indicators by teachers of the ISCED levels of education 1 and 2. The main objective of the presented part of the research survey was to find out in what way teachers perceive selected conceptual indicators related to the area of education of socially disadvantaged pupils.

The problem was defined by the question whether there were differences between teachers in the Pardubice Region and teachers in the Moravian-Silesian Region in what way they understood selected conceptual indicators related to the area of education of pupils with social disadvantage.

The hypothesis was defined as follows: There are differences between teachers in the Pardubice Region and teachers in the Moravian-Silesian Region in what way they understand selected conceptual indicators related to the area of education of pupils with social disadvantage. 


\subsection{Semantic differential}

Semantic differential is a specific method enabling to gain an insight into the individual meaning of terms in the respondents' interpretation. (Pelikán, 2011, p. 144). What is characteristic of this method is the interconnection of psycholinguistics, psychology of perception and psychology of individual consciousness (Maršálová, et al., 1990). This method was elaborated by Ch. Osgood and his colleagues (G. J Succi, P. H. Tannenbaum) on the basis of many studies; they stated that every term can be perceived on the basis of three aspects (evaluation factor, potency factor, activity factor) defining the position $\mathrm{f}$ such conceptual indicator in the so-called semantic space.

Osgood worked on the assumption that a certain object has both a denotative meaning and a connotative meaning with an individual (Osgood et al., 1975). It is possible to determine the individual meaning of key terms and their semantic proximity by means of this method (Osgood et al., 1975).

Despite the fact that semantic potential is regarded a method measuring attitudes ${ }^{3}$ of an individual towards the given term by some authors; we are inclined to those authors who work on the assumption that this method cannot measure the conation of an attitude absolutely safely, and this is why we speak about partial components of an attitude, or about measuring of meanings (Nakonečný 1997, p. 100).

The principle of this method is similar to that of rating methods. Respondents record their opinions of assessed terms on several-points scales consisting of opposite adjectives (Chráska, 2007).

\subsection{Characteristics of the research sample}

The research sample consisted of teachers of elementary schools in the Moravian-Silesian Region and the Pardubice Region. Church schools, schools established specifically for children with disabilities, alternative and international schools were not included in the sample due to our endeavour to capture the specifics of common elementary schools. All the schools on the ISCED levels 1 and 2 in the selected regions (according to the list in the registry of elementary schools updated on November 24, 2011) were addressed. The research tool was available in the electronic form on a created website. $A$ request for filling in the particular items was addressed to teachers of elementary schools in the selected regions and a request of filling in the questionnaire was sent to headmasters of these schools at the same time. E-mail addresses of teachers and headmasters of these schools were obtained from the directory of schools and educational institutions found by the Ministry of Education, Youth and Sports of the Czech Republic.

3 It is necessary to point out that attitude is a multidimensional subtle and difficult-to-be-captured variable consisting of cognitive, emotional and conative components (Katz, D., Stotland, E., 1959). 
A total of 399 elementary schools were addressed. 251 elementary schools from the Moravian-Silesian Region and 148 from the Pardubice Region were addressed. A total of 197 questionnaires were returned. The following table characterizes the number of respondents according to regions. The basic research sample consisted of teachers of elementary schools on the ISCED levels 1 and 2 in the Pardubice Region and the Moravian-Silesian Region in the Czech Republic.

Table 1

Number of respondents according to regions

\begin{tabular}{|l|c|c|}
\hline Region & $\mathbf{n}_{\mathrm{j}}$ & $\mathbf{f}_{\mathbf{j}}$ \\
\hline Moravian-Silesian & 123 & 0.624 \\
\hline Pardubice & 74 & 0.376 \\
\hline$\Sigma$ & 197 & 1 \\
\hline
\end{tabular}

\subsection{Conceptual indicators and their assessment}

Thirteen basic conceptual indicators related to social disadvantage were stated in the realized research survey on the basis of consultations with elementary school teachers and staffs of educational and psychological counselling centres. These conceptual indicators were: pupil with special educational needs, socially disadvantaged pupil, pupil of an ethnic minority, socially disadvantaged family, Roma, social disadvantage, inclusion, unstimulating family environment, homelessness, unemployment, poverty, culturally different environment and ethnic minority.

The respondents assessed the given indicators by means of 12 scales of semantic differential after being instructed to mark the field of the below mentioned polarity scales which most corresponds with their perception of the given term. Only one choice could be marked for each pair of polarities.

Evaluation factor: pleasant - unpleasant, beautiful - ugly, good - bad, bright - dark.

Activity factor: rounded - angular, active - passive, fast - slow, sharp - dull.

Potency factor: coarse - soft, strong - weak, deep - shallow, heavy - light.

The items of semantic differential were originally designed so that all the three factors (constructs) of individual perception of the selected terms by the respondents - the evaluation, activity and potency factors - were examined.

The outcomes of all the respondents' $(n=197)$ assessment in all the conceptual indicators were used for the basic verification of construct validity. The verification was conducted on the basis of a classic explorative factor analysis in which (contrary to the Osgood's classic semantic differential) only two common factors were extracted. The content analysis in fact concluded that the scales pleasant - unpleasant, beautiful - ugly, good - bad, dark - bright measure the evaluation dimension and the scales slow - fast, 
weak - strong, dull - sharp, heavy - light measure the energy dimension ${ }^{4}$; the rest of the scales was left as "factor-impure" out of semantic differential as well as the further processing of the outcomes. It was confirmed by the explorative analysis (just as stated by M. Chráska, 2007) that the activity factor is a considerably subtle construct that can be interpreted incorrectly. The energy dimension expresses in this case to what extent a term is related with "effort", difficulties or activity.

\subsection{Presentation of selected outcomes of the research survey}

Differences among the ways of understanding of particular conceptual indicators in teachers in the Pardubice and Moravian-Silesian regions were verified by means of the Mann-Whitney $\mathrm{U}$ test as well as the Student t-test.

Table 2

Mann-Whitney U-test (indicators 1-6)

\begin{tabular}{|c|c|c|c|c|c|c|c|c|}
\hline \multirow{2}{*}{ Variable } & \multicolumn{8}{|c|}{$\begin{array}{l}\text { Mann-Whitney } \mathrm{U} \text { test (DATA-working) } \\
\text { According to variables pol4-DOTDEM } \\
\text { Marked tests are significant on level } p<.05000\end{array}$} \\
\hline & $\begin{array}{c}\text { Sum } \\
\text { of rank } \\
\text { scores b }\end{array}$ & $\begin{array}{l}\text { Sum } \\
\text { of rank } \\
\text { scores a }\end{array}$ & U & Z & Sign p & $Z$ (corr) & $\begin{array}{l}\text { Sign p } \\
\text { (corr) }\end{array}$ & $\mathrm{N}$ \\
\hline ZSVP-h & 7165.000 & 12338.00 & 4390.000 & -0.41416 & 0.678760 & -0.42170 & 0.673248 & 74 \\
\hline ZSVP-e & 7542.000 & 11961.00 & 4335.000 & 0.55608 & 0.578157 & 0.56120 & 0.574660 & 74 \\
\hline SZV-h & 7208.500 & 12294.50 & 4433.500 & -0.30191 & 0.762722 & -0.31162 & 0.755330 & 74 \\
\hline SZV-e & 7016.000 & 12487.00 & 4241.000 & -0.79864 & 0.424501 & -0.81621 & 0.414379 & 74 \\
\hline ZEM-h & 7096.500 & 12406.50 & 4321.500 & -0.59092 & 0.554578 & -0.61527 & 0.538376 & 74 \\
\hline ZEM-e & 6744.000 & 12759.00 & 3969.000 & -1.50051 & 0.133483 & -1.56521 & 0.117534 & 74 \\
\hline SZR-h & 7144.500 & 12358.50 & 4369.500 & -0.46706 & 0.640461 & -0.47712 & 0.633280 & 74 \\
\hline SZR-e & 6772.000 & 12731.00 & 3997.000 & -1.42826 & 0.153218 & -1.46559 & 0.142760 & 74 \\
\hline ROM-h & 7245.000 & 12258.00 & 4470.000 & -0.20772 & 0.835445 & -0.21091 & 0.832956 & 74 \\
\hline ROM-e & 6788.500 & 12714.50 & 4013.500 & -1.38568 & 0.165845 & -1.43609 & 0.150977 & 74 \\
\hline SZ-h & 7378.000 & 12125.00 & 4499.000 & 0.13289 & 0.894279 & 0.13515 & 0.892494 & 74 \\
\hline SZ-e & 6960.500 & 12542.50 & 4185.500 & -0.94185 & 0.346269 & -0.98990 & 0.322226 & 74 \\
\hline
\end{tabular}

Explanatory notes: $\mathrm{h}$ - evaluation factor, e - energy factor, ZSVP - pupil with special educational needs; SZV - socially disadvantaged pupil; ZEM - pupil of an ethnic minority; SZR socially disadvantaged family; SZ - social disadvantage.

4 The energy dimension shows what Osgood's potency and activity factor show in total. (Chráska, 2007, p. 228) 
Table 3

Mann-Whitney U-test (indicators 7-13)

\begin{tabular}{|l|c|c|c|c|c|c|c|c|}
\hline \multirow{2}{*}{ Variable } & \multicolumn{7}{|c|}{$\begin{array}{c}\text { Mann-Whitney U test (DATA-working) } \\
\text { According to variable pol4-DOTDEM } \\
\text { Marked tests are significant on level p <.05000 }\end{array}$} \\
\cline { 2 - 11 } & $\begin{array}{c}\text { Sum } \\
\text { of rank } \\
\text { scores b }\end{array}$ & $\begin{array}{c}\text { Sum } \\
\text { of rank } \\
\text { scores a }\end{array}$ & U & Z & Sign p & Z (corr) & $\begin{array}{c}\text { Sign p } \\
\text { (corr) }\end{array}$ & N \\
\hline INCLN-h & 6848.500 & 12654.50 & 4073.500 & -1.23086 & 0.218377 & -1.29060 & 0.196843 & 74 \\
\hline INCL-e & 6595.500 & 12907.50 & 3820.500 & -1.88370 & 0.059606 & -2.00496 & $0.044968^{*}$ & 74 \\
\hline NRP-h & 7063.000 & 12440.00 & 4288.000 & -0.67736 & 0.498179 & -0.68952 & 0.490495 & 74 \\
\hline NRP-e & 7440.000 & 12063.00 & 4437.000 & 0.29288 & 0.769616 & 0.29520 & 0.767840 & 74 \\
\hline BZD-h & 7153.500 & 12349.50 & 4378.500 & -0.44383 & 0.657165 & -0.47113 & 0.637549 & 74 \\
\hline BZD-e & 7515.000 & 11988.00 & 4362.000 & 0.48641 & 0.626678 & 0.49476 & 0.620773 & 74 \\
\hline NEZ-h & 7004.500 & 12498.50 & 4229.500 & -0.82831 & 0.407494 & -0.83931 & 0.401297 & 74 \\
\hline NEZ-e & 7682.500 & 11820.50 & 4194.500 & 0.91863 & 0.358291 & 0.93721 & 0.348654 & 74 \\
\hline CHUD-h & 7441.500 & 12061.50 & 4435.500 & 0.29675 & 0.766659 & 0.29911 & 0.764858 & 74 \\
\hline CHUD-e & 8114.000 & 11389.00 & 3763.000 & 2.03208 & 0.042147 & 2.09361 & $0.036295^{*}$ & 74 \\
\hline KOP-h & 7580.500 & 11922.50 & 4296.500 & 0.65543 & 0.512194 & 0.73773 & 0.460679 & 74 \\
\hline KOP-e & 7445.500 & 12057.50 & 4431.500 & 0.30707 & 0.758791 & 0.39885 & 0.690004 & 74 \\
\hline NM-h & 7000.500 & 12502.50 & 4225.500 & -0.83863 & 0.401675 & -1.06100 & 0.288689 & 74 \\
\hline NM-e & 6787.500 & 12715.50 & 4012.500 & -1.38826 & 0.165058 & -1.99558 & $0.045981^{*}$ & 74 \\
\hline
\end{tabular}

Explanatory notes: $\mathrm{h}$ - evaluation factor; e - energy factor; INCL - Inclusion; NRP - unstimulating family background; BZD - homelessness; NEZ - unemployment; CHUD - poverty; KOP - culturally different environment; $\mathrm{NM}$ - ethnic minority.

Values of significance $p<0.05$ are marked in Tables no. 2 and 3. Only three indicators (INCLUSION, POVERTY and ETHNIC MINORITY) demonstrated statistically significant differences among assessment of the conceptual indicators by teachers from the Moravian-Silesian and Pardubice regions, namely in the energy dimension. 
Table 4

\section{T-test of students (indicators 1-6)}

\begin{tabular}{|l|c|c|c|c|c|c|c|c|c|}
\hline \multirow{2}{*}{ Variable } & \multicolumn{7}{|c|}{ t-tests; grouped:pol4-DOTDEM (DATA-working) } \\
Group 1: b \\
Group 2: a
\end{tabular}

Explanatory notes: $\mathrm{h}$ - evaluation factor; e - energy factor; ZSVP - pupil with special educational needs; SZV - socially disadvantaged pupil; ZEM - pupil from an ethnic minority; SZR - socially disadvantaged family; ROM - Roma; SZ - social disadvantage 
Table 5

T-test of students (indicators 7-13)

\begin{tabular}{|l|c|c|c|c|c|c|c|c|c|}
\hline \multirow{2}{*}{ Variable } & \multicolumn{7}{|c|}{ t-tests; grouped:pol4-DOTDEM (DATA-working) } \\
Group 1: b \\
Group 2: a
\end{tabular}

Explanatory notes: $\mathrm{h}$ - evaluation factor; $\mathrm{e}$ - energy factor; INCL - Inclusion; NRP - unstimulating family environment; BZD - homelessness; NEZ - unemployment; CHUD - poverty; KOP - culturally different environment; NM - ethnic minority.

The more sensitive Student t-test confirmed the statistically significant difference in the assessment of conceptual indicators in teachers from the Moravian-Silesian and Pardubice regions only in one indicator (POVERTY), namely in the energy dimension.

The outcome may be related to the difference between the regions in the number of socially disadvantaged persons (as well as the higher unemployment rate), and thus to the respondents' different experience. It is evident from the table that the teachers from the Pardubice Region relate the term POVERTY to greater "demanding nature", "difficulty" and "troubles".

The teachers from both the Pardubice and Moravian-Silesian regions perceive the term POVERTY "negatively" from the perspective of the evaluation factor in comparison to the other conceptual indicators. It is necessary to note that the evaluation factor characterizes the perception of the term on the basis of our primary evaluation (i. e. in the context of "the good" and "the evil"). 
A better idea can be got from the graphic image of semantic spaces of teachers from both the regions in Charts no. 1 and 2 based on the average evaluation of particular conceptual indicators what was verified also on the level of mode due to great sensitivity of the arithmetic mean for extreme values.

\section{Chart 1}

Semantic space of teachers of the Pardubice Region

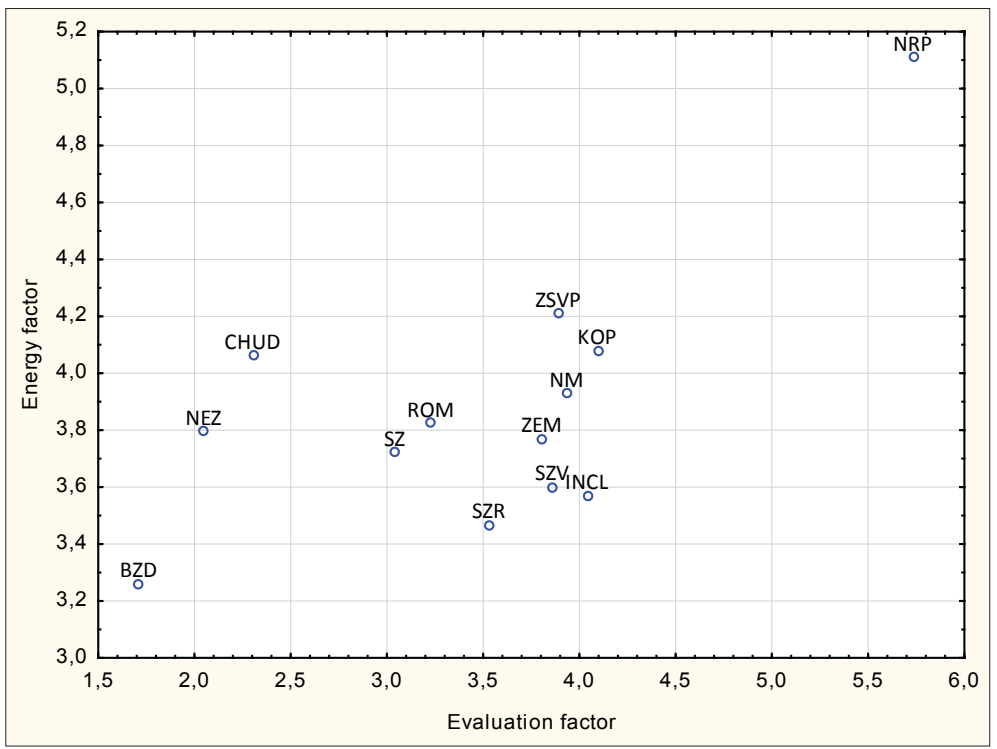

Explanatory notes: ZSVP - pupil with special educational needs; SZV - socially disadvantaged pupil; ZEM - pupil from an ethnic minority; SZR - socially disadvantaged family; SZ - social disadvantage; ROM - Roma; NRP - unstimulating family environment; BZD - homelessness; NEZ - unemployment; CHUD - poverty; KOP - culturally different environment; NM - ethnic minority; INCL - Inclusion. 


\section{Chart 2}

Semantic space of teachers of the Moravian-Silesian Region

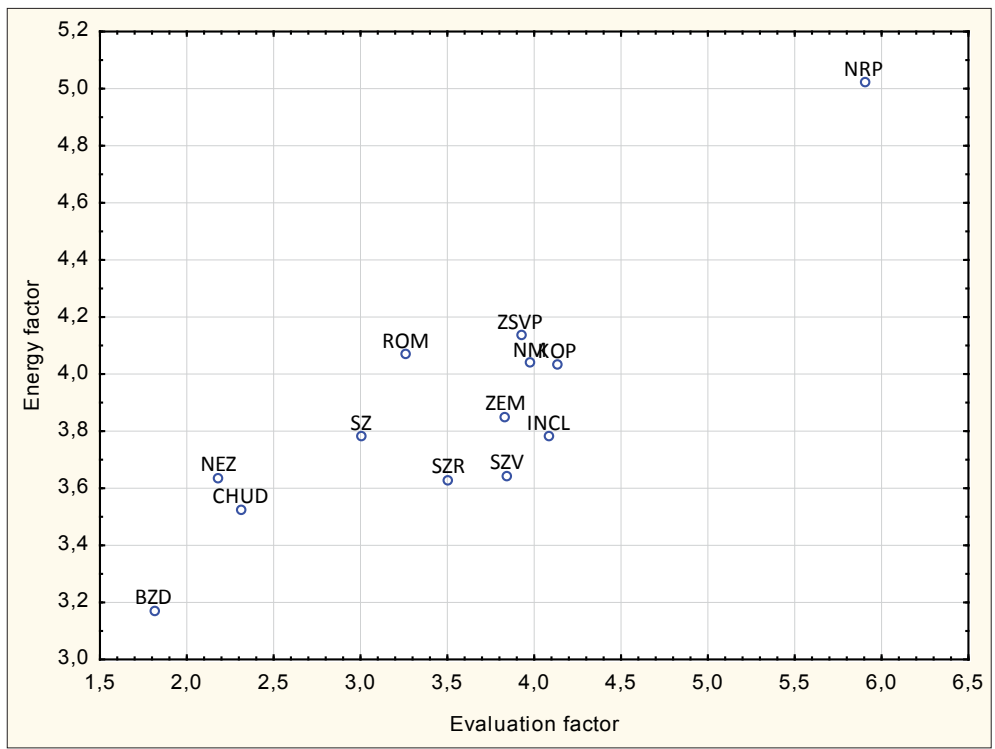

Explanatory notes: ZSVP - pupil with special educational needs; SZV - socially disadvantaged pupil; ZEM - pupil from an ethnic minority; SZR - socially disadvantaged family; SZ - social disadvantage; ROM - Roma; NRP - unstimulating family environment; BZD - homelessness; NEZ - unemployment; CHUD - poverty; KOP - culturally different environment; NM - ethnic minority; INCL - Inclusion.

The data obtained from the respondents from both the regions are identical in the following. The highest values in the evaluation and energy factors in both the regions are demonstrated in the term UNSTIMULATING FAMILY ENVIRONMENT what seems surprising from our perspective because this term was evaluated as relatively positive (the evaluation factor) with an investment of relatively great energy (the energy factor). This situation can be explained by the fact resulting from the entire matter of the examined issue of education of socially disadvantaged pupils in the Czech educational environment because the definition, specifics and characteristics of unstimulating family environment can be demanding for teachers from the diagnostic viewpoint; thus the high average value of both the factors can be explained by the assumption that teachers did not know "how to deal with the particular term". It is apparent from the table that teachers perceive the terms INCLUSION and CULTURALLY DIFFERENT ENVIRONMENT relatively positively. The terms PUPIL WITH SPECIAL EDUCATINAL NEEDS, SOCIALLY DISADVANTAGED PUPIL and PUPIL FROM AN ETHNIC MINORITY and ETHNIC MINORITY are perceived neutrally up to slightly negatively from the viewpoint of the 
evaluation factor. The term SOCIALLY DISADVANTAGED FAMILY was perceived more favourably in the evaluation factor by the respondents from both the examined regions in comparison to the above mentioned conceptual indicators, nevertheless more positively than the term ROMA and the term SOCIAL DISADVANTAGE; these are evaluated rather negatively by the respondents in comparison with the other terms. A relatively significant value difference can be observed in values of the above mentioned terms and the following terms which are evaluated more negatively by the respondents. These are the term UNEMPLOYMENT and POVERTY. The term HOMELESSNESS is perceived in the most negative way.

The term PUPIL WITH SPECIAL EDUCATIONAL NEEDS was labelled as the most "difficult", "demanding" and "problematic" by the respondents from the viewpoint of the order of particular terms according to the average score in the energy factor related to change, effort, activity; in our opinion this is understandable because this group of pupils includes pupils with physical handicap, physical disadvantage and social disadvantage according to the Education Act (s. 16 Act no. 561/2004 Coll.). It is a large group of pupils whose education in the educational mainstream places specific demands on teachers. The terms CULTURALLY DIFFERENT ENVIRONMENT, ETHNIC MINORITY, ROMA and PUPIL FROM AN ETHNIC MINORITY are perceived similarly by the respondents and related to a relatively greater deal of energy. The terms SOCIAL DISADVANTAGE and POVERTY were given a similar score in the energy factor; the terms UNEMPLOYMENT, SOCIALLY DISADVANTAGED PUPIL and SOCIALLY DISADVANTAGED FAMILY relate to a somewhat smaller deal of energy. The term demanding the smallest deal of energy is HOMELESSNESS according to the respondents.

\section{Conclusion}

A teacher's role in the area of education of socially disadvantaged pupils and surmounting of their disadvantage is absolutely crucial. Partial outcomes of a research survey focused on partial aspects of attitudes in relation to education of socially disadvantaged pupils were presented in the contribution.

Semantic differential used in the research survey enables a deeper insight in the individual understanding of particular terms related to the examined reality (in the case of the presented research survey in the area of education of socially disadvantaged pupils). (Pelikán, 2011, p. 149). The processing of the data obtained by means of this method enables us to gain a better insight in the teachers' concept of the examined area from their point of view.

The research survey was based on the assumption that there are differences between the respondents' perception of terms related to education of socially disadvantaged pupils in the Pardubice and Moravian-Silesian regions. The starting point was especially sociocognitive theories documenting a great number of social factors 
influencing the educational process in relation to a child. These factors can be e.g. the influence of classmates, teachers, pupils' self-evaluation, their relationships to their parents, their cultural and social background - these can influence their relationship to education. (Bertrand, 1998)

The research survey demonstrated that the teachers from the Pardubice Region relate the conceptual indicator POVERTY to greater "effort", "difficulties" than the teachers from the Moravian-Silesian Region. This situation may be conditioned by the fact that, beside others, teachers' attitudes are influenced also by social environment in which they act and by their individual experience.

We believe that it is appropriate to focus on the role of teachers, their position and competences in relation to education of all pupils (this fact is even intensified in the case of education of socially disadvantaged pupils) because it is possible to search opportunities for an optimum support of teachers only on the basis of the definition and specification of the above mentioned facts; this is because according to the OECD study Teachers Matter (2005) it is the quality of teachers and their pedagogical work that is the most important factor influencing the students' performance.

\section{References}

Bertrend, Yves. (1998). Soudobé teorie vzdělávání. Praha: Portál.

Breakdown Britain: Educational Failure. [online]. (2006). The Centre for Social Justice. [cit. 2013-04-03]. Retrieved from: <http://www.centreforsocialjustice.org.uk/client/downloads/BB_educational_failure.pdf>.

Coleman, S., James. (1966). Equality of Educational Opportunity. Washington, DC: US GoB Vernment Printing.

Coleman, S., James. (1988). Social Capital in the Creation of Human-Capital. American Journal of Sociology. 94, 95-120.

Conger, Rand \& Brent Donnelan. (2007). An Interactionist Perspective on the Socioeconomics Context of Human Development. [online]. Annual Review of Psychology. [cit. 4. 4. 2013]. Retrieved from http://www.colorado.edu/ibs/jessor/psych7536-805/readings/conger_donnellan-2007.pdf.

Clegg, Judy \& Jane GINSBORG. (2006). Language and Social Disadvantage: Theory into Practice. West Sussex, England:Wiley-Blackwell.

Český statistický úřad. (2012). Zaměstnanost a nezaměstnanost $v$ ČR podle výsledů výběrového šetření pracovních sil 4. čtvrtletí 2011. [online]. ČSú, 2. 4. 2012. [cit. 2013-05-05]. Retrieved from: <http://www.czso.cz/csu/2011edicniplan.nsf/p/3101-11>.

Equity and Quality in Education: Supporting Disadvantaged Students and Schools. (2012). OECD Publishing.

Executive Summary: Breakthrough Britain: Educational Failure. [online]. 2007. The Centre for Social Justice. [cit. 2013-04-03]. Retrieved from: <http://www.centreforsocialjustice.org.uk/client/ downloads/education.pdf $>$.

Havighurst, J., Robert. (1965). Who Are the Socially Disadvantaged? The Journal of Negro Education. 34, 1, 39-46. 
Helus, Zdeněk and Jiří Pelikán. (1984). Preferenční postoje učitelů k žákům a jejich vliv na účinnost výchovně vzdělávacího procesu. Praha: Výzkumný ústav odborného školství.

Chráska, Miroslav. (2007) Metody pedagogického výzkumu. Praha: Grada.

Jeřábek, Jan et al. (2006). Rámcový vzdělávací program pro základní vzdělávání: s prílohou upravující vzdělávání žáku s lehkým mentálním postižením. Praha: VúP.

Katz, Daniel \& Ezra Stotland. (1959). A Preliminary Statement to a Theory of Attitude Structure and Change. In Koch, Sigmund. (ed.). Psychology: A Study of a Science, Vol. 3, 423-475. New York: McGraw-Hill.

Kellaghan, Thomas. (1997). Family and Schooling. In L. J. Saha, (Ed.). International Encyclopedia of the Sociology of Education, (pp. 606-613). Oxford: Pergamon.

Kocourková, Vladimíra \& Anna Šafránková. (2011). Teoretická východiska analýzy postojů učitelů základních škol ve vztahu k edukaci sociálně znevýhodněných žáků. In M. Bargel, E. JAROSZ \& M. JŮZL, (Eds.). Sociální pedagogika v souvislostech globální krize. Sborník príspěvků z mezinárodní konference. (pp. 434-440). Brno: IMS.

Maršálová, L. \& Mikšík, O. (1990). Metodológia a metody psychologického výskumu. Bratislava: SPN.

Metodické doporučení k zabezpečení rovných přiležitostí ve vzdělávání dětí, žáků a žákyň se sociálním znevýhodněním. Č. j. 27607/2009 -60. [online]. 2009. Praha: MŠMT [cit. 2013-05-05]. Retrieved from: $<$ http://info.edu.cz/cs/taxonomy/term/112>.

Možný, I. (2002). Sociologie rodiny. Praha: Sociologické nakladatelství.

Nakonečný, M. (1997). Encyklopedie obecné psychologie. Praha: Academia.

Osgood, C. E., Suci, G. J., \& Tannenbaum, P. H. (1975). The measurement of meaning. Urbana: University of Illinois Press.

O'Sullivan, E., Gilligan, R., \& National Youth Federation (Ireland). (1997). No school, no future. Dublin: National Youth Federation.

Palečková, J., Tomášek, V. \& BASL, J. (2010). Hlavní zjištění výzkumu PISA 2009: Umíme ještě číst? Praha: Ústav pro informace ve vzdělávání.

Potměšil, M. (2010). Pocity, postoje a obavy pedagogických pracovníků ve vztahu k inkluzivnímu vzdělávání. In HAVEL, J. \& FILOVÁ, H. et al. Inkluzivní vzdělávání v primární škole - Inclusive Education in Primary School. Brno: Paido.

Pelikán, J. (2011). Základy empirického výzkumu pedagogických jevů. Praha: Karolinum.

Rabušicová, M. et al. (2004). Škola a (versus) rodina. Brno: Masarykova univerzita..

Sheerens, J. (2004). Review of School Instructional Effectiveness Research, Paper commissioned for the EFA Global Monitoring Report 2005, The Quality Imperative. UNESCO.

Starý, K., Dvořák, D., Greger, D. \& Duschinská, K. (2012). Profesní rozvoj učitelů. Podpora učitelů pro zlepšování výsledků žáků. Praha: Karolinum.

Teachers Matter, Attracting, Developing and Retaining Effective Teachers: Education and Training Policy. (2005) Paris: OECD.

Vašutová, J. (1998). Profese učitele v měnícím se společenském kontextu. In Maňák J. \& V. Jůva. Aplikované sociální vědy v prípravě učitelů. Cesta k sociální a ekonomické restrukturaci. Brno: Paido.

Zákon č. 561/2004 Sb., o předškolním, základním, středním, vyšším odborném a jiném vzdělávání (školský zákon), ve znění pozdějších předpisů. In Sbírka zákonů. 2004, 190, pp. 10262-10324.

\section{Contact:}

PhDr. Vladimíra Kocourková, Ph.D, Mgr. Anna Šafránková

Palacký University, Olomouc, Faculty of Education

Žižkovo nám. 5, 77140 Olomouc

Tel.: 00420-585 635874

E-mail: vladimira.kocourkova@upol.cz

E-mail: anna.safrankova@upol.cz 